\title{
The brief analysis on the key problems in the process of building modern apprenticeship talent cultivation mode in Higher Vocational Colleges__ Taking the engineering cost specialty as an example
}

\author{
Xiuyan Zhang, Chengjie Luan, Xiaolin Zhang, Huiqin Yang, Xia Zhao \\ Department of Architectural Engineering, Binzhou Polytechnic, Binzhou, 256603, China \\ E-mail: 317698397@qq.com
}

Keywords: modern apprenticeship, talent cultivation mode, the engineering cost specialty, the key problems

\begin{abstract}
With the improvement of technology level, the construction industry has more and more requirements for practitioners. Higher vocational colleges must closely follow the pace of industrial upgrading, and actively improve the talent cultivation mode, so as to meet the new demand for talents in the development of the industry. Taking the engineering cost specialty as an example, this paper discusses the key problems in the process of building modern apprenticeship talent cultivation mode. This paper analyzes the five aspects of the orientation of the training objectives, the construction of the curriculum system, the optimization of the teaching staff, the reform of the teaching model and the improvement of the evaluation mechanism. Then the corresponding suggestions are given. It provides a theoretical reference for the construction and improvement of modern apprenticeship talent cultivation mode for higher vocational colleges.
\end{abstract}

\section{Introduction}

With the progress of society and the development of science and technology, great changes have taken place in the mode of production in the construction industry, and the level of industrialization and the degree of intelligence have been greatly improved. Building information model, building assembly construction, green building and other new design and production methods have attracted more and more attention. Based on this, the requirements of the construction industry to its employees are becoming higher and higher. The skilled workers who only master the simple and repetitive work have become more and more difficult to meet the needs of the industry. They are replaced by those high skilled persons with solid theoretical foundation, excellent practical skills, excellent professional cultivation and certain innovative ability. As the training and output organization of skilled personnel, higher vocational colleges shoulder the responsibility of providing backup power for the transformation of the construction industry. It is necessary to follow the pace of industrial upgrading and actively improve the talent cultivation mode. In 2014, the State Council issued the "decision on accelerating the development of modern vocational education by the State Council". In 2014, the State Council issued the "decision on accelerating the development of modern vocational education by the State Council". It pointed out that "promoting the innovation of talent training mode", "carrying out the pilot of the modern apprenticeship in school-enterprise joint enrollment and joint training, perfecting the support policy, and promoting the integration of school and enterprise to educate people". Taking the engineering cost specialty as an example, this paper discusses the key problems in the process of building modern apprenticeship talent cultivation mode in higher vocational colleges.

\section{Applicability analysis of modern apprenticeship talent cultivation mode to the engineering cost specialty}

The department of architecture engineering of our college has three professional directions, namely construction technology, engineering cost and architectural art design. Among them, the 
engineering cost specialty is a professional with strong practicality and skill. With the industrial upgrading of the construction industry, especially the popularization and application of BIM software, many changes have taken place in the work mode, thinking mode and business scope of the engineering cost specialty. In the mode of work, the multi person cooperation platform will gradually replace the single computer software; in the thinking mode, the cost analysis through the building model will gradually replace the traditional cost analysis of the digital level. In the business cycle, the cost consultation of the whole life cycle of the building will replace the cost consultation of the single construction stage. On this basis, it is not enough for the students of the engineering cost specialty to master a little theoretical knowledge. They should also have an accurate grasp of the industry and market dynamics, have a skilled operation on the advanced software in the industry, maintain a certain degree of sensitivity to the frontiers of the industry, and have practical skills to analyze and solve problems. This requires that students must follow the pace of industrial upgrading, go to the enterprise to practice exercise, master the most advanced work mode, fully participate in the project, and "practice in learning and learn in practice" based on the theoretical study. The talent cultivation mode of modern apprenticeship gives expression to the training and assessment of students by schools and enterprises together under the guidance of the government and the dispatch of the industry association. It can make it realize that the curriculum standard fits the industry standard, the teaching content fits the post demand, and the students can get dual certificate of academic certificate and vocational qualification certificate when they graduate. Then it realize the "zero distance to the post". It can be seen that the engineering cost specialty is very suitable for the modern apprenticeship talent cultivation mode.

\section{The key problems in the process of building modern apprenticeship talent cultivation mode}

The construction of the modern apprenticeship talent cultivation mode needs the concerted efforts and extensive participation of the government, industry associations, enterprises, colleges and universities, and even the whole society. Among them, colleges and universities, as one of the main bodies of implementing modern apprenticeship, have an inescapable responsibility and obligation for the advancement of modern apprenticeship. Colleges and universities must play a good role in their own leading role, deepen education and teaching reform of the modern apprenticeship, and actively build a modern apprenticeship talent cultivation mode to adapt to the needs of talents in industry development and industrial upgrading. This article analyzes the key problems of the modern apprenticeship talent cultivation mode from five aspects.

\subsection{The orientation of the training objectives}

The development of building industrialization and intelligence has put forward higher requirements for practitioners in the engineering cost industry. As the cradle of high skilled talents, higher vocational colleges should better practice the talent cultivation mode of modern apprenticeship. First of all, it is necessary to have a clear orientation to the training objectives. In order to meet the requirements of industrial upgrading, higher vocational colleges should fully discuss with the enterprise experts, and then understand the requirements of the enterprise, update and expand the original training objectives, which must cover the four aspects of theoretical knowledge, practical skills, professional accomplishment and innovative potential. At the level of theoretical knowledge, students must have a good reserve of theoretical knowledge, and have a good grasp of the industry standards, laws and regulations, and the core courses of the major. At the level of practical skills, students are required to be proficient in software operation and grasp the basic business of engineering cost. They are competent for post functions and create social values. At the level of professional quality, students are required to form good professional ethics, strive for progress, and love and be dedicated to their job. On the level of innovation potential, students are required to maintain keen insight and active thinking, keep pace with the times, and have the spirit of improvement and innovation. 


\subsection{The construction of the curriculum system}

Higher vocational colleges should take the professional ability as the main line and jointly develop the curriculum system of production and education combined with enterprises. In the communication and discussion with the enterprise experts, we fully understand the professional ability demand of the cost enterprise to the employees, and build the curriculum system which integrates the theoretical knowledge module, the practical skill module, the professional accomplishment module and the innovation potential module. Among them, public courses and professional core courses are compulsory courses. In order to facilitate students' choice of courses related to vocational qualification certificates, vocational ability elective courses should be added in elective courses. In the course arrangement, theoretical and practical courses are interspersed, and compulsory courses are overlapped with elective courses. In apprenticeship talent cultivation mode, the construction of curriculum system should be dynamic. By obtaining feedback information from employers and front-line apprentices, we should adjust and optimize the curriculum system in a timely manner. In addition, on the basis of the construction of the curriculum system, the curriculum resources are actively developed to form a rich course resource package. The resource package can be uploaded and published on the teaching platform so that the students in the enterprise can learn and reference anytime and anywhere.

\subsection{The optimization of teachers' team}

In order to build the modern apprenticeship talent cultivation mode in higher vocational colleges, we must have a highly qualified teaching staff. The optimization of teaching staff can be started from the following four aspects. First of all, we must strengthen the training of the teachers. The full-time teachers should be actively organized and encouraged to participate in all kinds of training and improve themselves. Teachers' training can make teachers receive advanced teaching ideas and methods, develop strong ability of scientific research and high-level of scientific research, and make the education and teaching state and scientific research service ability keep pace with the times. Secondly, teachers should be encouraged to go to enterprises for training. During the period of building the modern apprenticeship system, it is far from enough that teachers only have theoretical knowledge of the reserve. They must have strong practical skills and rich experience in the project. This requires higher vocational teachers to participate in training regularly in enterprises, keep pace with the development of the industry, and continuously improve the level of business. Thirdly, the teachers' access mechanism and evaluation mechanism should be improved. In the links of teacher recruitment and professional title evaluation, practical skills are taken as one of the indicators of assessment and evaluation. We should change the past shortcomings of "emphasizing education and despising skills", and comprehensively enhance the practice level of teachers. Fourthly, the part-time teachers of enterprises can be introduced. The strategy of "please come in" can be adopted. We can employ the technical backbone of the enterprise and the expert of the industry to be a part-time teacher in the college, and they can teach the practical and hands-on course of the students. This not only enriches the teaching staff, but also provides guidance for students who are on probation.

\subsection{The reform of teaching mode}

The traditional teaching of higher vocational education is generally "knowledge based" education, while the modern apprenticeship talent cultivation mode should take "ability based" education and pay more attention to the cultivation of students' comprehensive quality and working ability. In the course of teaching, the typical task of the engineering cost is decomposed, and the teaching mode of task driven and project oriented is adopted in combination with the project case. This kind of teaching mode is much easier for students to build scenarios, so that students can clearly identify tasks, generate interest and gain a sense of achievement. In the reform of the teaching mode, teachers should make full use of modern teaching methods and teaching platforms to realize the information teaching. For example, we can use "cloud class" to organize students to sign in and answer in class, to publish homework after class. And teachers can organize all kinds of 
tests, launch brainstorming and voting activities. And the teaching resources can be uploaded to the platform for students to read and learn at anytime and anywhere. In addition, in the reform of teaching mode, teachers should renew their ideas and actively adopt advanced methods to implement teaching. For example, teachers can enhance students' interest in learning by introducing micro class, flipped classroom, the QR code, WeChat public number and other forms of students' pleasure.

\subsection{The improvement of evaluation mechanism}

The evaluation mechanism about the modern apprenticeship talent cultivation mode mainly includes two parts, the first one is the school evaluation, and the second one is the enterprise evaluation. The school evaluation is usually conducted in the form of examination according to the performance of students in school. For the courses with strong theory, written examination is often adopted. While the manner of practical examination is adopted for the courses with strong operability. The school evaluation mechanism has gradually matured through long-term practice and exploration. In the enterprise evaluation mechanism, the evaluation of the "apprenticeship" in the enterprise is given by the "master" and the enterprise. How to ensure that the evaluation is reasonable, true, fair and effective? The corresponding suggestions are given in this paper as follows: (1) The industry association, as a third party organization, make sure the process control and quality supervision of the training and evaluation of the enterprise. (2) The modern apprenticeship doesn't mean a single practice. It needs the close collaboration between the school and enterprise. And the higher vocational college should assign the teacher to the enterprise to understand the students regularly. This can make sure the problem can be solved in time. (3) After many arguments, the enterprises should formulate the contents and methods of evaluation rationally. And the enterprise takes strict consideration of the comprehensive quality of "master" so as to ensure that "master" has excellent professional skills and good professional ethics. (4) The acquisition and certification of apprenticeship vocational qualification certificate can be as a supplement to enterprise evaluation.

\section{Conclusion}

The industrial upgrading of the construction industry has put forward higher requirements for its employees. The implementation of the modern apprenticeship talent cultivation mode complies with the trend of industrial development, and has promoted the students' practical skills and comprehensive quality. Taking the engineering cost specialty as an example, this paper discusses the key problems in the process of building modern apprenticeship talent cultivation mode. This paper analyzes the five aspects of the orientation of the training objectives, the construction of the curriculum system, the optimization of the teaching staff, the reform of the teaching model and the improvement of the evaluation mechanism. And the corresponding suggestions are given. These provide theoretical reference for the construction and improvement of the modern apprenticeship talent cultivation mode in higher vocational colleges.

\section{Acknowledgements}

Research and practice of training model of professional personnel in higher vocational engineering under modern apprenticeship (ZJXH2017202), Construction and development of engineering cost curriculum in higher vocational colleges based on apprenticeship system.

\section{References}

[1] Huaguo Jiang. Discussion on application of "modern apprenticeship" talent cultivation mode for engineering cost specialty -- Taking Luzhou Vocational and Technical College's Engineering Cost specialty as an example. Journal of Luzhou Vocational and Technical College. 2015(2):5-7.

[2] Lihua Huang. Innovation and practice of modern apprenticeship talent cultivation mode for 
Engineering Cost Specialty -- Taking Zhejiang Guangsha College of Applied Construction Technology as an example. Journal of Chongqing Electronic Engineering Career Academy. 2017(9):123-125.

[3] Dongmei Chen. Research on the talent cultivation mode of modern apprenticeship in Higher Vocational Colleges. Theory and Practice of Education. 2015:31-32

[4] Yamei Zhang. Study on the training mode of modern apprenticeship oriented talents in Higher Vocational Colleges. Hebei Normal University of Science and Technology. 2016.

[5] Wanyu Lu. Research on the Model of Modern Apprenticeship in Higher Vocational Education. Dalian University. 2011.

[6] Wanyu Lu, Hongbin Wang. The building of the talent cultivation mode of modern apprenticeship in Higher Vocational Colleges with Chinese characteristics. Journal of Liaoning Higher Vocational Education. 2013(1):21-24.

[7] Lianming Zhao. Research on modern apprenticeship training mode in Higher Vocational Colleges. Education and Profession. 2017(8):40-43. 